\title{
Science education reform in Confucian learning cultures: teachers' perspectives on policy and practice in Taiwan 儒家學習文化對科學教育改革的可能影響:臺灣自然科教 師之觀點分析
}

\author{
Ying-Syuan Huang ${ }^{1} \cdot$ Anila Asghar ${ }^{1}$
}

Received: 11 September 2015/Accepted: 4 April 2016/Published online: 12 October 2016

(C) The Author(s) 2016. This article is an open access publication

\begin{abstract}
This empirical study investigates secondary science teachers' perspectives on science education reform in Taiwan and reflects how these teachers have been negotiating constructivist and learner-centered pedagogical approaches in contemporary science education. It also explores the challenges that teachers encounter while shifting their pedagogical focus from traditional approaches to teaching science to an active engagement in students' learning. Multiple sources of qualitative data were obtained, including individual interviews with science teachers and teachers' reflective journals about Confucianism in relation to their educational philosophies. Thematic analysis and constant comparative method were used to analyze the data. The findings revealed that Confucian traditions play a significant role in shaping educational practices in Taiwan and profoundly influence teachers' epistemological beliefs and their actual classroom practice. Indeed, science teachers' perspectives on Confucian learning traditions played a key role in supporting or obstructing their pedagogical commitments to inquiry-based and learner-centered approaches. This study draws on the literature concerning teachers' professional struggles and identity construction during educational reform. Specifically, we explore the ways in which teachers respond to educational changes and negotiate their professional identities. We employed various theories of identity construction to understand teachers' struggles and challenges while wrestling with competing traditional and reform-based pedagogical approaches. Attending to these struggles and the ways in which they inform the development of a teacher's professional identity is vital for sustaining current and future educational reform in Taiwan as well as in other Eastern cultures. These findings have important implications for teachers' professional development programs in East Asian cultures.
\end{abstract}

Keywords Education reform - Science education - East Asian culture $\cdot$ Confucian learning culture $\cdot$ Teacher identity

Lead editor: A. Hussénius.

Ying-Syuan Huang

ying.huang6@mail.mcgill.ca

Anila Asghar

anila.asghar@mcgill.ca

1 Department of Integrated Studies in Education, McGill University, 3700 rue McTavish, Montreal, QC H3A 1Y2, Canada 
摘要 本研究之目的,是在探討臺灣國民中學自然科教師,對於科學教育改革等相關議 題之看法,並分析臺灣自然科教師如何落實建構式教學法; 最後,本研究也試圖了解自 然科教師從傳統講授式教學,調整為以學生為中心的教學法時,所面臨的教學困境。本 研究採質性的研究方法,藉由兩次的半結構深度訪談,蒐集十位臺灣國民中學自然科教 師的教學經驗,以及他們對於臺灣科學教育改革的想法;受訪者並受邀撰寫教學省思 日誌,日誌主要 $\square$ 容為:回顧臺灣的教學現狀,以及申論儒家教育理念對於臺灣教學現 場可能 $\square$ 生的影響。本研究分析顯示:傳統儒家思想對臺灣教師的教學哲理有深遠的 影響,而研究中的自然科教師,也普遍認為,傳統儒家思想阻礙了探究式教學法的進一 步發展,並對於落實以學生為中心的教學形式,添增了許多不確定性與難度。藉由教 師專業認同等相關理論,本研究並針對自然科教師在新教學方法與教育改革的衝擊下, 如何取擇傳統講授式或建構式等教學法。本研究結果指出,深入探討教育改革與教師 專業認同等相關議題有其必要性;而相關研究將有助於加強臺灣科學教師的師資培育, 以及針對儒家文化圈中,教師專業認同等發展,提出適當的策略與建議。

This study is situated against the backdrop of the science education reform movement that was initiated by the Taiwanese government in the 1990s. Prior to the reform, the education system in Taiwan was centrally controlled by the Ministry of Education. In the 1990s, a demand for educational reform emerged from the citizens because of the growing dissatisfaction with the government's control over curriculum and assessment. The Minister of Education, Cheng-sheng Tu, explained the origin of the reform movement in the following statement (2007):

On April 10, 1994, Taiwan's middle-class citizens organized and staged a mass demonstration demanding educational reform. The movement, later called "The 410 Demonstration for Education Reform," has become a landmark in Taiwan's history. Its main appeal was to demand the removal of all unreasonable controls and bondages imposed on education by the authoritarian government and to return to the student-centered educational liberation movement. It demanded a shift of the concepts of "de-centralization" to "individualization." (p. 12)

In particular, Taiwan's citizens "demanded a shift of the concepts of 'de-centralization' to "individualization"” (Tu 2007, p. 12) to develop a system that would foster teacher and student autonomy. In response to these demands, the government overhauled the Basic Law of Education and enacted a series of reform policies pertaining to teacher preparation programs and the national curriculum for K-12 education. The key goals of this reform were to cultivate students" conceptions of "democracy" and their "ability to think, judge and create" (Ministry of Education 2013, p. 8).

The new curriculum in science was fully promulgated in 2004. In parallel with global developments in education, active-learning and problem-based approaches became the central focus of Taiwan's science education reform program (Ministry of Education 2012). In particular, the most comprehensive reform policy document, the White Paper for Science Education (Ministry of Education 2003), was published and implemented at K-12 levels in the early 2000s. The White Paper proposed that "students' independent thinking," and their "potential for active learning," and "creating new technology should be developed" (p. 14) through science education.

Given that active inquiry by students is at the core of the recent reform initiatives, Taiwanese science teachers have been encouraged by the Ministry to engage in learner- 
centered teaching practices. Specifically, in the classroom setting, where active inquiry and independent thinking are highly encouraged, the teacher's role has been transformed from that of a knowledge transmitter to that of a coach supporting students in meaning-making and knowledge-construction processes (Fosnot 1996). As such, students are to be given more autonomy and opportunities to become active agents in their own learning (Anderson 2002). According to the Ministry of Education policy documents, instructional and evaluation strategies should be shifted to enable students to participate actively in knowledge construction in order to develop essential scientific literacy competencies, such as analytical reasoning, critical thinking, conceptual understanding and problem-solving skills (Ministry of Education 2003). This shift requires teachers to adopt a variety of new instructional strategies to meet individual students' needs (Blanchard, Southerland and Granger 2009).

However, active learning approaches contrast with traditional Taiwanese lecturebased teaching methods. A large number of Taiwanese teachers have strongly resisted the reform-based science standards and curricula (Chiu and Whitebread 2011). Many secondary-level science teachers have reported feeling incompetent in implementing the new curriculum, as their professional training has not prepared them to teach using learner-centered constructivist strategies (Kyriacou and Chien 2004). Furthermore, many teachers and parents feel that the new approaches are not compatible with Taiwanese cultural values (Baron and Chen 2012). In particular, the highly competitive examination system has led to a learning environment in which teaching and learning activities primarily focused on how to best prepare students' for college entrance tests (Tsai and Kuo 2008). Consequently, parents are worried that the scientific knowledge that their children have been exposed in the new curriculum might be insufficient to succeed in national standardized examinations. Despite strong opposition to the reform, the Ministry of Education has continued to make efforts to implement these initiatives in Taiwanese educational institutions. Over the past decade, science-learning objectives (e.g., developing students' critical thinking, problem solving and scientific literacy) have remained at the core of the current national science curriculum (Ministry of Education 2003). At the same time, debate on the effectiveness of the reform has continued among Taiwanese scholars, teachers and policy leaders. Some teachers insist that direct methods of teaching are straightforward and effective, whereas the new pedagogy is too complex and confusing for students.

The challenge of implementing reform-based practices seems to be an old story within educational communities around the world due to a variety of cultural and institutional factors. To our surprise, we learned that recent scholarship has highlighted Chinese traditional values as the potential reason for the gap between reform policies and actual classroom practices in East Asian cultures (Lu, Cowie and Jones 2010). Discussions about the role of Confucian traditions in influencing teaching approaches suggest that instruction in these cultures primarily focuses on transmitting knowledge from teachers to students such as direct instruction and lectures-based methods (Yang, Huang and Aldridge 2002). Some scholars have argued that these traditional approaches are based on Confucius' way of teaching. For instance, Roger Tweed and Darrin Lehman (2003) have contended that "Confucian learning involves passivity" (p. 148), and this view has led to a debate in the literature. Some researchers defend the Confucian approach for upholding deep thinking, introspection and contemplation. They contend that knowledge is gained through persistent effort, perseverance and passion in the Confucian tradition (Watkins and Biggs 1996). Jasper Kim (2002) also asserted that although Western scholars may assume that students' 
silence means they are acquiring knowledge passively, many East Asians believe that silence is beneficial to high levels of thinking. This approach to fostering reflective thinking has thus been deemed a notable feature of the Confucian learning heritage (Li 2003).

Indeed, Confucius' values and learning traditions continue to shape the educational systems and approaches-including science curriculum and instruction-in Taiwanese schools in many ways (Huang 2014). However, very few studies have addressed the myriad ways in which Eastern cultural values interact with constructivist science teaching approaches. Our study attempts to address this gap in the literature. We seek to understand how Confucian values are interpreted in the context of contemporary science education and the cultural challenges involved in implementing the reform-based science curricula in East Asian cultures. Specifically, we explore the ways in which teachers respond to educational changes and negotiate their professional identities. We employed various theories of identity construction to understand teachers' struggles and challenges while wrestling with competing cultural and reform-based pedagogical approaches. Given that the learner-centered approaches introduced by the reform were largely developed in Western cultures, we were interested in understanding how Taiwanese teachers deal with traditional values that conflict with reform-based approaches to teaching and learning science.

In light of the above, this study seeks to investigate a number of important questions concerning the implementation of Taiwan's science education reform. It attempts to explore secondary science teachers' (Grade 7-9) perspectives on the reform policies, as well as investigate the issues and challenges faced by Taiwanese teachers while implementing the reform-based pedagogy. At the same time, we seek to understand teachers' professional needs in achieving the curriculum goals set forth by the reform policies. Following are the research questions guiding this study: (1) How do secondary science teachers perceive and understand the science education policy? (2) How do they learn about the policy and curriculum goals? (3) What epistemological approaches are they committed to and using in their practice? (4) What are their views about Confucianism and its role in education? (5) How, if at all, do Confucian learning traditions inform their teaching practice?

\section{Understanding the study context}

The present article is a part of a larger research project that explored Taiwanese policymakers' and science teachers' perspectives on the challenges involved in implementing the science curriculum reform in Taiwanese schools (Huang 2014). Our analysis of the data revealed that the policymakers believed that certain Confucian learning traditions posed significant obstacles to the implementation of the new science curriculum, which focuses on developing innovation and critical-thinking skills in students (Huang 2014). The policy leaders who participated in our study also asserted that "the emphasis on maintaining a harmonious social order in Confucianism has led to excessive social conformity" (Huang 2014, pp. 104-105) in Taiwan's education system. However, during the first phase of this research, none of the teacher participants talked about the educational reform in relation to Confucian learning traditions. In order to explore teachers' perspectives on Confucian learning traditions vis-à-vis the reform, the teacher participants were invited to participate 
in follow-up interviews and journal writing. Details of the research instruments are explained in the methodology section of this article.

Since the profound influence of Confucian learning traditions in Chinese society is vital to our inquiry, we begin the following section by describing the features of Confucian philosophy that have been instrumental in shaping the cultural and educational values in Taiwanese society. We then discuss the theoretical frameworks that informed this study.

\section{The Confucian legacy in Taiwanese society}

East Asian learning environments, including those in Japan, South Korea, Hong Kong and Taiwan, are often seen as grounded in Confucian values and traditions. Confucius (551 BCE-479 BCE) is considered to be the "Great Sage"- the greatest teacher-in Chinese history. His central value, ren (仁), reflects compassion and affection; to practice ren, people should treat others as they wish to be treated. Confucius believed that if everyone practiced ren, children would respect elders and siblings, friends would be kind to each other, citizens would be grateful to their government and governmental officials would love their citizens. Therefore, a harmonious society and peaceful world could be created based on these values (Nivison and Van 1996). In addition, Confucius encouraged people to learn from the past and study classic literature, because he believed that learning helps to cultivate one's virtues. He suggested that everyone should be devoted to self-cultivation, learning and practicing ren to promote harmony in the society (Lai 2008).

Confucius' students came from many different regions of China to seek knowledge and to study with him. He accepted them regardless of class, gender or social status, and thus became the first teacher to make education available to all citizens in ancient China (Yao 1999). He is therefore recognized as Wan Shi Shi Biao (萬世師表), the model teacher of every age. The status of teachers in East Asian society reflects Confucius' status; they are highly respected as experts, mentors and role models for their students. To achieve ren a teacher should teach wen (文, letters), xin (行, ethics), zhon (忠, loyalty and devotion) and xin (信, truthfulness) (Nivison and Van 1996).

In 1991, Sun Yat-sen, the national father of Taiwan, formed the government based on Confucian philosophy. Thus, Confucius' key educational principles-you jiao wu lei (有教 無類, education for all children) and yin chai shi jiao (因材施教, teaching in accordance with students' abilities) — have significantly shaped the national philosophy of modern Taiwanese society as a whole (Lin 1983). In particular, Confucius believed that there should be no class distinction with respect to teaching. Therefore, education should be available to all individuals in the society. As Confucius said, "From the man bringing his bundle of dried flesh for my teaching, I have never refused instruction to anyone" (Confucius, trans. 1907, p. 389).

Confucius also deeply emphasized the importance of knowing students' individual needs and guiding students in accordance with their interests and strengths. He thus believed that a good teacher should be able to teach in accordance with students' abilities and meet the learning needs of his students-yin chai shi jiao (因材施教). A story in the Analects of Confucius illustrates his views on this subject: "When one student, K'ew, asked Confucius whether or not he should immediately apply what he had learned, Confucius told K'ew to consult his father and elder brothers first. However, when another student, Yew, asked Confucius the same question, Confucius answered in the affirmative. When he was asked about his decisions, Confucius said, 'Yew is retiring and slow; therefore, I urged him forwards. K' ew has more than his own share of energy; therefore, I key him back.'” (Confucius, trans. 1960, p. 108). 
Even today, you jiao wu lei (education for all children) and yin chai shi jiao (teaching in accordance with students' abilities) remain the key principles in Taiwan's education system. In accordance with you jiao wu lei, the most recent education policy (Ministry of Education 2012) mandates 12 years of affordable education for all students. The government reiterates the national commitment to yin chai shi jiao in the White Paper on Education (Ministry of Education 2012):

[T]he implementation of a sound 12-year compulsory education and preschool education is based on the concepts of teaching without prejudice or discrimination.... Education in Taiwan should not only focus on teaching in line with the student's ability (yin chai shi jiao)... but also cultivating students' virtues and moral education. (pp. 6-9)

The predominant influence of Confucian values in East Asian societies has been widely discussed by scholars. However, some scholars have also examined the legacy of the imperial examination system (keiju, 科舉) that existed in China from the Sui dynasty (581$618 \mathrm{CE}$ ) to the beginning of the 20th century (Feng 1995). The purpose of the imperial examination system was to select talented people who were loyal to the autocracy (Elman 2000). Yuan Feng (1995) notes that loyalty and absolute obedience to authority were heavily emphasized in this system. Successful candidates were required to demonstrate advanced literary skills and a mastery of the Confucian classics. During the Ming (1368$1644 \mathrm{CE})$ and Qing (1644-1911 CE) dynasties, an extremely rigid structure of essay writing一 $b a g u$ wen (八股文, eight-legged essay)—was developed. Examinees were required to follow the exact format, and were also restricted from developing new ideas that were not included in the Confucian classics. In the late Qing dynasty, many Chinese intellectuals criticized the rigidness of the eight-legged essay (Mohan and Lo 1985). They also believed that the imperial examination system nurtured obedience to authority. In addition, the examination requirements led Chinese students to have little interest in learning science and mathematics, because the Confucian classics were the only test materials (Elman 2000). As a result, after approximately 1300 years, Emperor Guangxu abolished the imperial examination system in 1905 (Miyazaki 1976).

The legacy of the imperial examination system has remained an integral part of contemporary Chinese society. For example, the system provided the citizens-who were not from privileged families but with political ambitious - an avenue for social mobility. Successful candidates were guaranteed political positions for life that would bring honour and wealth to their families. Thus, even today, Chinese parents tend to have high expectations for their children to achieve excellent academic performance (Francis and Archer 2005). Several studies have shown that Chinese parents and students deeply believe in the idea of social mobility through hard work and high examination scores (Stevenson and Stigler 1992). A parent participant in Jun Li's (2001) study with Chinese parents also expressed the belief that all Chinese parents would encourage their children to strive for academic excellence because "only if you excel in your studies will you have a good future" (p. 482). In the same vein, in another study, most secondary students in Taiwan self-reported that their motivation for learning science was mainly to prepare for tests in order to achieve high marks (Tsai and Kuo 2008).

Interestingly, Chinese parents appear to view key Confucian values such as diligence and self-improvement as the collective cultural legacy that contributes to their children's academic success (Li 2001). This has led to a growing scholarly discussion on the influence of Confucian values on learning environments in East Asian countries (e.g., China, South Korea, Japan, Hong Kong and Taiwan) (Rao and Chan 2009; Wang 2013). Benjamin 
Elman (2000) asserted that East Asian culture has been dominated by Confucian values because the emperors successfully "equated social and political order with moral and political indoctrination" (p. 131) through the imperial examination system. Nonetheless, their influence on contemporary classroom practice has yet to be fully explored.

A few scholars have attempted to unravel the influence of Confucian values and examination culture on Chinese education system. For example, Feng (1995) compared the imperial examination structure with that of the contemporary National College Entrance Examination in China. The study suggests that both systems have established a reputation of fairness, such that they are trusted by the majority of Chinese people (Feng 1995). They have also been symbolized as providing equal access to opportunities for social mobility because those who achieve high scores on the National College Entrance Examination are likely to have an assured professional career. Moreover, the Confucian classics—sishu (四 書, the Four Books) and wujing (五經, the Five Classics) — constitute core subjects for both of these examinations. Indeed, secondary and post-secondary schools in Taiwan are still required to teach The Analects of Confucius - the collection of Confucius's sayings and ideas as recorded by his apprentices (Chou and Ching 2012).

Drawing on the legacy of the imperial examination system and the influence of Confucian values in the Taiwanese educational environment, this study seeks to understand how teachers' cultural values might shape their responses to modern educational reform.

\section{Developing a theoretical framework for understanding teachers' identities}

In this section, we discuss the literature on science education reform in relation to teachers' professional identities. In particular, we examine how educational reforms might lead to conflicts in teachers' professional practice. The discussion then turns to theories of identity development, in order to understand how teachers negotiate their professional identities in the context of reform.

\section{Teachers' conflicts with educational reforms}

One of the major challenges for teachers in the twenty-first century is a shift in curricular focus. New standards for science education focus on student-centered and inquiry-based pedagogies to foster scientific competencies in learners, such as critical thinking, inquiry skills, and problem solving through application of scientific knowledge. These pedagogical changes have also transformed the role of teachers in the classroom. Today, the reformbased approaches expect science teachers to encourage their students to engage in active inquiry and conceptual thinking (Osborne and Dillon 2008). Thus, teachers are important stakeholders in curricular development, as well as critical agents of change in the implementation of educational reforms.

The shift in curricular focus requires teachers to have a deeper understanding of individual students' characteristics-interests, attitudes, competencies and needs-to design supportive learning environments that meet the needs of each student. Furthermore, the effectiveness of learner-centered teaching depends on teachers' ability to constantly adjust their professional practice. They are expected to guide students in complex inquiry tasks, such as solving problems collaboratively by using evidence-based reasoning while simultaneously attending to students' individual needs (Bybee 2002). Leading a learnercentered classroom in the contemporary educational system is, therefore, a more complex and delicate act than in the past (Weimer 2002). 
A number of scholars have found that the shifting role of teachers has led to a myriad of conflicts and struggles in their teaching practice (Smith and Southerland 2007). Teachers today often experience stress, anxiety, and uncertainty as they implement reform-based curricula (Van Veen and Sleegers 2006). For example, Jari Hakanen, Arnold Bakker and Wilmar Schaufeli (2006) found that science teachers were concerned about the additional workload imposed upon them, as the new curriculum required them to spend more time preparing their lessons and learning new teaching strategies. As a result of the increased workload, teachers felt less motivated to adopt the new curriculum and teaching approaches.

Several studies have indicated that unclear reform policies often lead to confusion, misconceptions and resistance to change among teachers (Cohen and Hill 2001). As noted earlier, prior to the reform, the curricula for K-12 education and teacher education in Taiwan were centrally controlled by the Ministry of Education (Tu 2007). Schools were allowed to use only those teaching materials that were prescribed by the National Institute for Compilation and Translation. Moreover, teachers were expected to use the teaching methods that were approved by the Ministry of Education; these curricular mainly emphasized direct and lecture-based instruction. Therefore, teachers were used to teaching the textbook content that was mainly developed and assigned by the Ministry of Education officials (Chou and Ching 2012). With the education reform of the 1990s, private textbook publishers were given the freedom to compile and publish textbooks for K-12 levels. Teachers were encouraged to use creative pedagogies and were offered the autonomy to select their own teaching materials to meet reform-based curricular and instructional goals. Nonetheless, many Taiwanese teachers felt that the new curriculum framework and textbooks did not help them in reforming their instruction because they did not receive any professional training to apply these approaches in their practice. In a study that investigated 203 Taiwanese primary school teachers' attitudes toward education reform, Chris Kyriacou and Pei-Yu Chien (2004) found that most teachers were disappointed by the unclear reform policies and curriculum goals. Though policy leaders intended the reform-based curriculum to provide teachers with more freedom and autonomy, over $70 \%$ of the teachers in this study reported high levels of stress and anxiety at work because the broad curriculum guidelines did not actually support them in classroom teaching.

Other studies also indicate that stress and frustration amongst teachers lead to a lack of trust in the reform (Spillane and Thompson 1997). This culture of distrust, according to Megan Tschannen-Moran and Wayne Hoy (2000), generates feelings of uncertainty, anxiety and insecurity in teachers. These negative emotions can, in turn, strongly affect teachers' capacity to think, plan and retain information (LeDoux 1998). Importantly, these attitudes may prompt teachers to respond defensively and manage stress by focusing only on the approaches which they are most comfortable with. In other words, teachers may choose to implement only selected features of the reform in their practice.

In exploring teachers' negative reactions to reform initiatives, Michelle Collay (2006) asserted that the mainstream discourse on reform has neglected to account for the social and cultural contexts of teaching, such as a teacher's race, gender, cultural background and epistemological beliefs. Indeed, a handful of studies on teaching approaches in various cultures have highlighted significant differences between teaching practices in Western countries and East Asian countries, including Singapore, mainland China, Hong Kong, Taiwan, South Korea and Japan (Biggs 1998). For instance, East Asian teachers might perceive the teacher-centered learning environment as being most effective because its pedagogical practice parallels Confucian learning traditions in their view. Many East Asian teachers also believe that students learn less when they engage in hands-on activities; they 
feel that learning requires students to follow traditional classroom discipline routines, such as listening to their teachers and respecting them (Tao, Oliver and Venville 2013). Nguyen Phuong-Mai, Cees Terlouw and Albert Pilot (2006) argue that, in East Asian countries, teachers' cultural beliefs and teaching philosophies may not be congruent with learnercentered approaches and this could have a considerable impact on constructivist reform initiatives.

In a study comparing the constructivist teaching practices in a Japanese and an American mathematics classroom, James Stigler and James Hiebert (1998) found that although the Japanese teachers tried to adjust their practice to the constructivist teaching model by engaging students in classroom discussions, the classroom remained as a teachercentered and content-learning oriented environment. Students continued to look to teachers for evaluation of correct problem-solving strategies and standarized answers to given tasks. Consequently, classroom discussions tended to rely on the traditional "initiation-responseevaluation sequence" (Cartier, Smith, Stein and Ross 2013, p. 11), wherein a teacher's questions were meant to solicit fact recall rather than encouraging students to express their own ideas. Due to their "superficial engagement" with constructivist approaches, the Japanese teachers in Stigler and Hiebert's (1998) study reported that they saw little improvement in students' conceptual understanding and critical thinking despite their efforts to engage in interactive approaches that accommodated the pedagogical changes. Drawing from our own experience as science educators, we acknowledge how this feeling of disappointment could lead teachers to believe that taking extra time and effort to use non-traditional teaching methods is impractical.

Professional development and support in any reform initiative is critical. Therefore, in addition to making policies to enriching teaching practice with new pedagogies, the policymakers must also devise programs to engage teachers in critical reflection on their own teaching philosophies in relation to the reform objectives (Alsup 2006). Scholars in other fields have underscored the importance of respecting the practitioner as a person (Danielewicz 2001) in any professional development initiative. For example, in professions such as medicine, nursing and radiology, constructing one's professional identity is one of the key components of professional development. Several studies have suggested that a critical reflection on their emerging professional identities during their training has helped medical residents to recognize their particular roles and responsibilities in hospitals, where working conditions are complex (Jarvis-Selinger, Pratt and Regehr 2012). Moreover, primary-care physicians with a deeper awareness of their professional identities tend to have better interpersonal competencies and skills to deal with different groups of people at work, such as patients, colleagues, administrators and other professionals in the field (Gardner 2007). Michael Pratt, Kevin Rockmann and Jeffery Kaufmann (2006) emphasize that establishing professional identities develops integrity and belief systems that support life-long professional learning for health specialists. In a study with 166 experienced health professionals across four European countries, Simone Kirpal (2004) found that constructing professional identities helped the participants resolve work-related stress, encouraged their emotional involvement with patients, and alleviated feelings of professional uncertainty. In other words, a stronger professional identity has helped medical professionals balance work efficiency and quality of care by developing the ability to manage conflicting demands of patients, families and administration.

We argue that teachers' professional—and personal-identities should be valued in the professional development discourse. In order to recognize the value systems that teachers bring to their professional roles, many scholars have echoed the pressing need to appreciate 
teachers' personal identities, which comprise their prior beliefs, experiences, personal values and cultural convictions, in conjunction with their professional identities (Olsen 2008). Looking at their personal beliefs and cultural values regarding education might generate greater understanding about how teachers respond to change (Aikenhead 2006). In a Confucian learning culture, for example, teachers' responses to educational reform cannot be understood without examining their personal views and cultural learning traditions. Drawing on the literature concerning teachers' struggles in implementing reformbased curricula, we believe that attending to these challenges is vital to support teachers during educational change. Specifically, in this study, identity construction frameworks allowed us to understand our participant teachers' personal and professional identities while trying to implement reform-based curricula in Taiwan. Thus, in the following section, we discuss the identity frameworks that we used for this study to examine how teachers negotiate their professional identities in the context of educational change.

\section{Identity theories and teacher identity}

Teacher identity broadly refers to a teacher's self-concept in relation to his or her professional role. A teacher's identity and professional practice are shaped by a number of internal factors (e.g., values, beliefs, emotions) and external circumstances (e.g., professional development, teaching conditions, social surroundings). At the same time, these internal and external factors are inextricably connected. When teachers face a shift in curricular focus or working conditions, such as implementing reform policies, they must adjust their professional identities to adopt different roles and teaching philosophies. Thus, exploring the ways in which curriculum changes affect teachers' identities is critical to understand how teachers might respond to those changes.

April Lynn Luehmann (2007) notes that identity formation has four common characteristics:

1. Identity is constituted socially through interactions with others.

2. Identity is constantly shaped and reshaped, although changes in one's core identities require intensive effort and negotiation over a long period of time.

3. Identity is complex and "multifarious" as it consists of "a number of interrelated ways one is recognized as a certain kind of person, participating in social communities".

4. Identity is constructed through "interpretations and narrations of experiences" (Luehmann 2007, p. 827).

These characteristics suggest the importance of looking at the complex ways in which people continuously construct their personal and professional identities. In Confucian tradition, the primary goal of learning is to achieve the highest moral standard in society. Therefore, teachers are expected to support not only students' cognitive growth, but also their moral and character development (Ho, Peng and Chan 2001). In addition, teachers are highly regarded as experts whose role is to impart knowledge and wisdom, and students are expected to respect their authority in the classroom (Kennedy 2002). These personal and cultural values shape teachers' professional identities in important ways (Beijaard, Verloop and Vermunt 2000). Thus, understanding the cultural values that teachers bring into the classroom might help to explain how they negotiate the tensions between their existing practices and those required by the reform policies. 


\section{Identity crises and identity development}

The literature on identity crises also provided a useful lens through which to look at the internal conflicts that participating teachers experienced while adjusting their practice to Taiwan's education reform. According to Erik Erikson (1968), identity crisis refers to a stage in which individuals are engaged in an intense effort to resolve internal conflicts. For example, reexamining or re-evaluating one's roles in a profession, culture or society in order to find acceptance. Contemporary identity researchers have found that identity crises or identity transformations are partly inspired by social changes (Hardy and Kisling 2006). Furthermore, many aspects of individuals' social lives (e.g., family, occupation, race, class and gender) can initiate changes in their value systems and personal identities. Identity transformations can also occur in one's professional life. For example, a physician might experience an identity crisis while conducting a medical trial on patients, or a lawyer might feel conflicted when handling a legal case that contradicts his or her personal or professional beliefs and values.

Earlier, we discussed the key goals of science education reform and identified the challenges that teachers have faced worldwide while trying to adjust their practice in response educational reform. Drawing on past and current understandings of identity development, educators have also been interested in exploring teacher identity in relation to their struggles and challenges (Beauchamp and Thomas 2009). James Marcia's (1966) framework of identity development serves as a useful lens to illuminate the complex processes involved in identity (re)construction. Marcia (1966) defined identity crisis as a sequential process in which individuals reexamine their old values, explore alternative roles and actively choose new beliefs; this self-examination process may lead them to commit to new values or principles and integrate them into their existing belief systems.

According to Marcia (1966), individuals experience four psychological states in the process of identity development and transformation, which he describes as identity diffusion, foreclosure, moratorium and identity achievement. Marcia conceptualized these four identity states in relation to changing life circumstances, during which identity transformations occur based on choices or decisions that individuals make in relation to their values, beliefs, goals and roles (Kroger, Martinussen and Marcia 2010). Herein, we briefly present these identity states (Marcia 2002):

1. Identity diffusion In this state, individuals may be aware of their value systems, but they have not yet made an explicit commitment to a particular identity. In addition, they may or may not have experienced internal conflicts regarding their identity. For instance, when a person moves to a foreign country, he or she may encounter entirely different customs, values and cultural traditions. Although the experience of being different in the new environment may lead to a conscious awareness of his or her previous cultural experience and value systems, the individual may not explore a range of alternative options.

2. Foreclosure In this state, which precedes identity crisis, individuals have made a commitment to a particular identity. Often this identity is based on the beliefs and values expressed by their families and cultural traditions, which they tend to conform to and accept without questioning. For instance, at this stage, individuals may not clearly know whether their career goals are their own or come from their parents or role models. They try to become what their parents or role models want them to be and feel threatened when faced with a situation in which their prior values are no longer valid. 
3. Moratorium In this state, an individual is in the midst of an identity crisis while negotiating between competing value systems. Unlike those in other identity states, individuals at the moratorium stage are trying to resolve internal clashes in order to choose between different beliefs, goals or roles and commit to a coherent value system. However, they have not been able to resolve the contradictions completely.

4. Identity achievement In this state, individuals have become fully committed to a particular identity after going through an identity crisis, having sorted through the many possibilities of who they want to be. Coming to this established identity means that an individual has made an explicit commitment to a particular value system, professional role or life purpose (Marcia 2002).

Based on Marcia's framework, identity crisis and its transformation can occur not only in individuals' personal lives (e.g., death, love, loss of job, marriage, or relocation) but also in their professional settings, for example, during educational change. While dealing with mandatory pedagogical changes prescribed by the reform policies, some teachers might choose to ignore them altogether if they feel that the new curricular goals were not compatible with their existing values and beliefs about teaching and learning. Others may not make an effort to explore the reform-based practices and, therefore, continue with their existing practices. Hence, transforming one's personal beliefs and constructing a new professional identity is neither instantaneous nor easy (Reicher 2004). Therefore, expecting teachers to alter their epistemological beliefs, values and teaching habits in accordance with new educational approaches is not realistic. For instance, teachers in the moratorium identity state may need professional support and continuous professional development opportunities to help them resolve their internal pedagogical conflicts (Stephen, Fraser and Marcia 1992). Thus, teachers' professional development should take into account identity development and internal conflicts in the context of reform. Teachers should be supported in professional development programs to critically reflect on their teaching philosophies, personal values and professional goals in relation to the reform objectives.

\section{Contextualizing the study}

This study highlights how constructivist approaches to science education are resisted, or adapted, in a culture where traditions play a significant role in shaping educational practices. In this research, we viewed ourselves as "constructivist inquirers" (Lincoln and Guba 2013, p. 75)-researchers interested in exploring the complexity of teachers' historical, social and cultural experiences (Denzin and Lincoln 2000). This exploratory qualitative inquiry aimed to identify and assess the challenges that science teachers have been facing while implementing the mandatory reform-based curriculum in their classrooms.

\section{Participants, setting and context}

We used purposive sampling methods (Maxwell 1996) to recruit participants from local schools in Taiwan. Ten in-service teachers volunteered to participate in this study. They were certified to teach secondary science in the public school system and had graduated from the National Normal University in Taiwan. These teachers currently teach physics, chemistry, biology or earth sciences in various public schools in Taiwan. An overview of the participants' characteristics is presented in Table 1 (Participants' real names are not included in this paper. We have used aliases for all participants). 
Table 1 Participants' profile

\begin{tabular}{|c|c|c|c|c|c|}
\hline Name & Gender & Teaching subject(s) & $\begin{array}{l}\text { Teaching } \\
\text { experience } \\
\text { (in years) }\end{array}$ & Degree & $\begin{array}{l}\text { Geographical } \\
\text { location }\end{array}$ \\
\hline Zhong & M & Physics, chemistry & 7 & B.Ed. & Taipei city \\
\hline Xiao & M & Biology & 17 & B.Ed. & Taipei city \\
\hline Ren & M & $\begin{array}{l}\text { Physics, chemistry, earth } \\
\text { science }\end{array}$ & 24 & B.Ed. & Taipei city \\
\hline Bao & M & Physics, chemistry & 2 & B.Sc. & Nantou \\
\hline Jing & $\mathrm{F}$ & Biology & 4 & $\begin{array}{l}\text { B.Ed., M.Sc., Ph.D. (in } \\
\text { progress) }\end{array}$ & Taipei city \\
\hline Yi & M & Physics, chemistry & 12 & $\begin{array}{l}\text { B.Ed., M.Ed., Ph.D. (in } \\
\text { progress) }\end{array}$ & Kaohsiung \\
\hline Hei & M & Physics, chemistry & 27 & B.Ed. & Tainan \\
\hline Wei & $\mathrm{F}$ & Physics, chemistry & 3 & B.Ed. & Taichung \\
\hline Ting & M & Physics, chemistry, biology & 8 & B.Ed., M.Sc. & Hsinchu \\
\hline Chang & M & Biology & 9 & $\begin{array}{l}\text { B.Ed., M.Sc., Ph.D. (in } \\
\text { progress) }\end{array}$ & Taipei city \\
\hline
\end{tabular}

All ten teachers agreed to participate in individual interviews. The interview conversations focused on teachers' understanding of Taiwan's reform policies and the new curriculum goals. In addition, participants were encouraged to share their critical views about the issues or challenges that they encountered while trying to implement the reformbased curriculum in their classrooms.

As noted earlier, this article presents a small part of a larger research project (Huang 2014). In this research project, we were interested in exploring Taiwanese policymakers' and science teachers' perspectives on the reform. Initially, semi-structured interviews were conducted with ten secondary science teachers in Taiwan and three policymakers who had been involved in formulating the science education policy. After the first around of interviews, all policymakers suggested that Confucian teaching and learning traditions had led to tremendous challenges in relation to the implementation of the new science education reform. On the other hand, none of the teacher participant discussed the topic of Confucian learning cultures during the first round of interviews. This phenomenon thus prompted us to conduct a second phase of investigation in which we focused on exploring teachers' views about Confucian learning cultures and the challenges that they might have confronted while implementing the new teaching approaches.

In the second phase of this study, we initially invited the ten teacher participants who had taken part in the prior interviews to participate in writing a reflective journal and a second around of individual interview. Nine out of ten teachers have agreed to participate in writing reflective journals where they expressed their thoughts and perspectives on Confucianism and its role in Taiwan's educational system. They were invited to answer the following four open-ended questions in their reflective journals: (1) What does science learning mean to you? (2) What does your classroom teaching look like? (3) What are your views about Confucianism? and (4) What does Confucian teaching and learning culture mean to you? After writing their journals, these nine participants also agreed to take part in the second round of individual interviews (lasted between 60 and $90 \mathrm{~min}$ ), in which they 
responded to open-ended questions that were designed to elicit their values and beliefs around Confucian learning traditions in relation to their science teaching practices.

Face-to-face interviews were conducted with these participants in their schools in Mandarin Chinese by the first author. In addition, they were encouraged to write their reflective journals in Chinese so that they could express their thoughts and feelings candidly. The first author carefully transcribed the interviews into Mandarin Chinese. Later, the interview transcripts and reflective journals were translated into English for analysis (Creswell 2007). Moreover, follow-up discussions were held with teacher participants, including member checks, to seek their feedbacks on our interpretations of the data. Approximately $60 \%$ of the translated and de-identified interview transcripts were also reviewed by two of our colleagues whose mother tongue is Mandarin, but who are also fluent in English.

\section{Data analysis}

In this article, we discuss data collected and analyzed from two sources: (1) two rounds of individual interviews with secondary science teachers in Taiwan and (2) teachers' reflective journals. We used a number of qualitative analysis tools and techniques to analyze these data, such as thematic analysis, which involved categorizing and clustering salient themes emerging from the data. This approach allowed us to identify common patterns in different types of data (Denzin and Lincoln 2000) and explore participants' voices about their experiences during the reform. Salient concepts were identified by carefully reading the interview transcripts and reflective journals. Central themes that emerged from this analysis included Confucian moral values, respect for authority, professional support for teachers, commitment to traditional practices. Furthermore, we used concept maps and other visual displays (e.g., thematic matrices) to explore the relationships among various categories and themes (Maxwell 1996).

We also employed the constant comparative method to draw out patterns of similarities and differences (Holliday 2002). In particular, constant comparative analysis helped us to compare the policy documents with science teachers' vision for science education reform, and their views about science curriculum goals and professional support systems. This analytical approach also helped us critically compare teachers' understanding of Confucian learning traditions in relation to their teaching practice with their views on various challenges to the implementation of reform, as well as compare teachers' understanding of science education policy with their actual pedagogical practices. This method also enables us to compare participants' understanding and interpretations of Confucian learning traditions. The first author also maintained a reflective diary to record and examine her biases and assumptive interpretations of participants' meaning-making during the data collection process. Moreover, we constantly discussed and critically examined our interpretations during the analysis and writing process.

\section{Finding 1: Teachers' perspectives on science education reform and professional support in Taiwan}

In the first phase of this research, the participants were asked to share their views about the current science education reform in Taiwan and how well it was being implemented in local schools. The interviews revealed that most of the teachers did not find their teacher 
preparation and in-service education programs useful in terms of supporting them to implement the reform. They particularly emphasized that the in-service programs organized by the Ministry of Education were not relevant to their classroom practice as these programs did not expose them to practical strategies and skills that would help improve their teaching.

Six out of ten teachers noted that adequate professional development opportunities were not being provided to support those trying to implement inquiry- and competency-based approaches in their science classrooms. Their main concern about using these new methods was that they did not have sufficient experience and training to facilitate classroom discussions. For example, Jing - a biology teacher teaching for 4 years - who perceived promoting student-centered learning as the new science policy, said that she could not follow the new approaches because of time constraints and her lack of experience with active-learning methods. Other issues that emerged in these conversations included: a lack of connection between education policies and real classroom settings, insufficient instructional time, inadequate resources for teaching and learning, and pressure to prepare students for the national standardized examinations. The following excerpts highlight the challenges articulated by the participants:

Xiao: It is very challenging.... If we want to improve students' thinking, teachers need to have more time to train students to learn how important it is to think in science... [and] more time to check their answers to open-ended questions. I wanted to try, but in the end, I was trained to provide standardized answers.

Jing: I think I don't have enough training and time to try different teaching methods.... Even now with just lectures, I feel like I already need to rush through things in order to cover the curriculum content in a short amount of time before the exams.

Bao: The reform policy planning is too idealistic; the funding and resources are not enough for non-traditional science teaching. Moreover, I don't think I have received enough training on practicing learner-centered teaching and how to improve students' hands-on skills.

Moreover, seven out of ten teachers pointed out that policymakers didn't make any efforts to help the parents to understand the curriculum changes either. This communication gap led to enormous obstacles in their actual teaching practices. All participants felt that policy leaders needed to increase parents' as well as teachers' understanding of the new educational policies. Xiao, a biology teacher, shared his struggles in explaining the reform goals to parents. He said that when he tried to incorporate the new approaches in his teaching practice, such as using open-ended problems and encouraging students to develop different strategies to solve the given tasks, neither parents nor students could understand why there were no standard "right" answers to these problems. Consequently, Xiao felt that he was "wasting a lot of time and energy" explaining his teaching goals to the parents. In the end, he gave up on these strategies and decided to satisfy his students' and parents' expectations by returning to his traditional teaching methods. Similarly, Hei, who has taught physics and chemistry for 27 years, believed that policymakers did not fully understand teachers' actual needs. According to Hei,

Policymakers do not consider how parents think while creating these policies. Parents only care about exam scores. No matter how much effort a teacher puts in, parents will blame the teacher for not helping students improve their exam scores.... The policies and experts in the field of education don't really know our actual teaching situation. 
Additionally, Chang, a biology teacher who also acts as a mentor in the in-service teacher community, felt that policy planning and implementation measures did not address the issues that exist in actual classrooms. As an instructor in professional development programs, Chang has followed the developments in educational policy and planning closely. According to Chang, "The higher authorities make their policies... [but] the local people such as teachers and students have their countermeasures... The implementation is not successful because there is still a huge gap [between policy] and the reality in schools."

As discussed earlier, the science education reform emphasizes student-centered and inquiry-based teaching approaches as key strategies for improving students' scientific literacy. When teachers were invited to share their understanding of the reform policies during the interviews, we discovered different notions of what "learner-entered" means to them. In particular, over half of the participants thought that the current science curriculum promotes student-centered teaching approaches to improve students' hands-on skills, critical thinking and problem-solving competencies. Six out of ten teachers explained that learner-centered pedagogy places students at the center of the learning process. For these teachers, a student-centered classroom values hands-on and group activities (e.g., classroom presentations or outdoor observations) such that students actively participate in their own learning. Some teachers explained that the learner-centered approach involved understanding students' processes of thinking and identifying the challenges that they might face while learning science. Other teachers described learner-centered approaches as maintaining a fairly equal relationship between teachers and students. For example, Ting emphasized the importance of "talking to students like friends" through informal conversations after class. He believed that this approach had helped him "better understand students' learning progress" as well as "improve their motivation to learn." When further invited to share their understanding of critical thinking and problem-solving skills, seven out of ten teachers believed that students who have learned to think critically through science education are able to "apply scientific knowledge" and "use logical scientific explanations to describe daily life phenomena."

Our analysis also shows that about half of the participants thought that the reform policy emphasizes a rigorous preparation of Taiwanese students for the Programme for International Student Assessment (PISA). Some teachers said that they did not know any details about this international assessment program. They thought that PISA test meant "science literacy" and did now know how to teach it in their own class. When other teachers were invited to talk about their understanding of the PISA test, Zhong, a physics teacher, noted that this test requires teachers to teach problem-solving tasks to develop students' analytical thinking. Ren, who has taught physics and earth science teacher for 12 years, believed that PISA is another format of exam that aims to evaluate students' understanding of basic scientific concepts and problem-solving skills. The following excerpts demonstrate these teachers' understanding of the PISA test:

Zhone: The only new policy I know is the PISA test.... It asks teachers to provide different solutions instead of giving students the right answer directly. It also asks students to think of where the solutions come from.

Ren: The PISA test only tests students' basic knowledge and skills... It is simpler than what students are tested on in the traditional [national] exams in Taiwan.

Yi: $\quad$ The PISA test only focuses on basic life skills that students need to tackle practical day-to-day problems.

The Ministry of Education has established regional in-service education centers that are meant to create professional communities of teachers and provide them with relevant 
resources for implementing student-centered and inquiry-based approaches in local schools. Formal and informal professional resources are also outlined in the policy documents made available to teachers to facilitate the implementation of this policy. However, our analysis revealed that science teachers mostly tend to value the professional support from their colleagues, school-based teacher communities and online professional networks more than the programs offered by the Ministry. They prefer to participate in their local and online professional communities - through formal as well informal platforms-to exchange new ideas and teaching experiences with each other. For instance, Wei, a beginning physics teacher, explained that online group discussions helped her to develop new instructional materials and teaching skills. Specifically, she felt that "receiving feedback from other teachers on her ideas is more helpful" than the information she received in the in-service workshops held by the Ministry.

Today, teachers are required to fulfill a range of educational goals and expectations, and these are coupled with the imposition of multiple, seemingly unrelated reform initiatives. Policy leaders had hoped that introducing learner-centered and inquiry-based approaches in Taiwanese classrooms would encourage student autonomy, critical thinking and creativity. However, these transformations are not easy to achieve when teachers feel that they are not supported in implementing active learning methods in their classrooms. At the same time, such pedagogical change requires a significant shift in teachers' cultural values and professional commitments. Importantly, teacher preparation and professional training programs must provide increased opportunities to prospective and in-service teachers to experience and understand positive outcomes of reform-based pedagogies. In the following section we highlight the significance of cultural traditions in educational reform by illuminating the relationship between teachers' Confucian values and their epistemological beliefs about teaching.

\section{Finding 2: Teachers' cultural beliefs and teaching approaches}

In the second phase of this study, we were specifically interested in exploring teachers' epistemological beliefs about Confucianism. Teacher participants were encouraged to write about these issues in their reflective journals. After we had read their journals, they were invited to a second round of in-depth interviews, where conversations centered on their professional practice in relation to their understanding of Confucianism. Nine out of ten teachers participated in this second phase. In the following sections, we discuss our participants' perceptions of Confucian learning culture and the ways in which their understanding of Confucian learning traditions inspire their teaching practices.

\section{Confucian learning heritage: Education traditions and social discipline}

Across the interview conversations and journal entries, we found that all the teachers who participated in the second round of interviews discussed fundamental Confucian virtues, including courtesy, benevolence, respect, discipline, humility and a strong work ethic in regard to education. Importantly, all participants believed that the purpose of learning is to cultivate these virtues in students. At the same time, they expected their students to demonstrate Confucian virtues in the classroom as they believed that these values help in developing a balanced and harmonious society. As Hei, an experienced chemistry teacher, reflected in his journal: 
Confucianism emphasizes the development of one's personal character to develop harmonious relationships in society; it encourages civility; respect for elders; loyalty to friends, family members and superiors; and responsibility while performing one's duties. If these social relationships and Confucian traditions were established, peace would prevail in the world.

When the teachers were invited to share their perspectives on the relationship between Confucian learning culture and their teaching practice, a number of them discussed how Confucian values influenced their relationship with their students. For example, three participants suggested that "respect is at the heart of their relationship with their students," and that it is important to teach their students to respect teachers. They further explained that they expect their students to follow the classroom rules respectfully, believing that this develops self-discipline, which contributes to the larger social goal of "maintaining a balanced social order in society." Other Confucian virtues, such as developing personal character, perseverance and humanity, also emerged as a significant component of their teaching philosophy. Ting, who has been teaching physics, chemistry, and biology for 8 years, discussed the importance of building a collegial relationship with students in order to support their character development and felt that teachers should embody Confucian values to act as role models:

Through teaching we not only pass on knowledge, but also personal character. Therefore, teacher-student friendship is extremely important.... In order to best cultivate personal character, it is not enough to explain this in words; teachers should act as moral models for their students.

\section{Teachers' perspectives on scientific inquiry in a Confucian heritage culture}

As we analyzed the interview conversations and reflective journals, we noticed that, given their experience with active-learning pedagogies, some teachers had become conscious of potential limitations of Confucian learning traditions. For example, although all the teachers explained that Confucianism has played a positive role in shaping the Chinese society by cultivating moral virtues and preserving social harmony, six out of the nine teachers who participated in the second phase of this study also thought that Confucian traditions of self-discipline and respect for authority might constrain learners' autonomy, innovative thinking and free expression in the classroom. For example, Ting believed that the traditional teacher-centered pedagogy, which had been heavily influenced by Confucian learning traditions, conflicted with student-centered and discovery-oriented learning approaches. As he noted:

Ethical teaching in Confucianism has constrained your thinking and prevented you from thinking outside of the box. A student would have to constantly consider whether others would criticize your action of interrupting the class to raise questions, as well as expressing different ways of thinking.

In the same vein, $\mathrm{Yi}$ - a physics teacher-who had earlier stated in his reflective journal that Confucian values should be preserved in modern Taiwanese society, argued that these values may also inhibit students' expression. According to Yin, "since Confucianism promotes conformity as a goal for achieving societal harmony, most people in Taiwan are afraid of being different from others... and a few students dare to challenge their teachers or raise questions in class." Nevertheless, while talking about the role of inquiry in science 
during his second interview, he said that there would be "no scientific advancement or economic improvement without inquiry and creativity in science as science is based on free inquiry." This conflicted perspective also appears in another teacher's reflective journal and interview, where he expressed some uncertainty over the strengths and weaknesses of Confucian traditions. Although Hei-a physics and chemistry teacher-shared his strong beliefs about the role of Confucian principles of education in terms of inhibiting students' ability to challenge traditional educational and behavioral norms. He was concerned that modern science might not progress within the Chinese culture due to these traditions. As Hei explained:

Confucian philosophy overly focuses on individuals' virtues and greatness, as well as striving to live in harmony with others. These have led students in Confucian learning cultures to be afraid of challenging traditional norms and constructs.... The result is that modern science and objective knowledge cannot be developed within the Chinese culture.

It is important to note that all the participants underscored the importance of Confucian moral values and ethics for society at large. However, several teachers felt that certain Confucian values and traditional pedagogy tend to constrain creativity, critical thinking, innovation and scientific development. These conflicting beliefs have important implications for the implementation of reform-based pedagogy.

\section{Finding 3: Taiwanese science teachers' pedagogical beliefs and approaches}

In the following sections, we present Taiwanese science teachers' pedagogical approaches in light of Confucian epistemology to illustrate the various ways in which Confucianism has shaped their beliefs and actual classroom teaching practice.

\section{Commitment to traditional approaches}

Our findings suggest that some teachers were deeply committed to traditional science teaching approaches and resisted the science education reform. These teachers believed that a teacher should be able to enforce discipline in the classroom. For example, Ting, who has been teaching at a secondary school for 12 years, shared that guiding students' learning and maintaining discipline in the classroom were important features of his teaching practice. He believed that teacher-student relationships should be based on respect. In his words,

As a public school teacher, I see my role in building students' character and respect between individuals.... To be a responsible teacher, I have to instruct students to do their science experiments while maintaining the classroom discipline.

These participants also perceived their roles as role models for their students to inspire their ethical development. They viewed education as a cultural legacy and hoped to see Confucian traditions passed on to the next generation for the sake of maintaining social harmony. They appeared less open, therefore, to the teaching methods that are different from those of their own teachers and cultural traditions. For instance, Jing, who has been 
teaching secondary science for 4 years, explained that she was more comfortable with traditional and lecture-based teaching approaches. As Jing explained:

I grew up in a traditional learning environment and feel that I have learned science well through traditional methods.... My role as a teacher is to guide students in their learning. Although I may seem to be transmitting knowledge to them through lectures, I don't see anything wrong with this method, as I grew up learning in this way.

Importantly, these teachers noted that they had found the traditional methods to be useful in their own learning experiences. Viewing their own teachers as instructional role models, they believed that the role of an educator is to help students memorize scientific knowledge and concepts. They did not want to deviate from traditional approaches and felt that direct teaching methods were effective and efficient. Thus, they continue to rely on traditional teaching methods in their classroom practices.

Zhong, who has been teaching at a secondary school for 7 years, discussed his beliefs about the importance of classroom discipline in student learning. He believed that students could only learn well when the classroom rules are followed in his class. During the interview, Zhong reflected on his own learning experiences with lecture-based instruction. He insisted that "lecturing is still the most effective method for students to achieve academic success [and the] most effective and efficient way to learn," because it had helped both him and his students succeed academically in the past. Although Zhong had learned about the cooperative learning strategies during his pre-service training, he was not comfortable with losing control over his students' learning. He emphasized that "[a] teacher's role is to help students earn high scores in exams so that they can pursue successful careers in their lives." Zhong also shared his difficult experience with using group learning methods in his instruction: "It was a mess, as most of the discussions in class were not relevant to the science concepts... and I had a hard time monitoring students' learning progress.... Thus, I now stick to the traditional teaching methods." Zhong believed that innovative thinking led to overthinking the science content and felt that students tend to get distracted in discussions and could not concentrate on the course content. Ting and Jing also shared similar perspectives on teaching and learning. All three believed that respect for teachers and classroom discipline should be enforced to maintain the Confucian learning traditions. They also felt more comfortable in leading students' learning and maintaining classroom discipline using traditional methods.

\section{Straddling between traditional and learner-centered approaches}

Some participants shared their dilemmas about traditional teaching methods that they had been experiencing. We noticed a conflict between some teachers' beliefs about learnercentered teaching approaches and their actual teaching practices. In particular, they believed that while traditional lecture-based teaching methods were efficient, they were not effective in developing students' reasoning, creativity and critical inquiry skills. These teachers also highlighted the conflicts involved in making compromises in their teaching practice in light of the external pressures they faced from an examination-oriented education system. While they felt that inquiry-based strategies would be useful in developing their students' critical-thinking and problem-solving skills, they decided to use traditional teaching methods to prepare students for standardized exams.

We use an excerpt from Yi's interview conversation here as an example to illustrate these teachers' experiences. During his interview conversations, Yi, a physics and chemistry teacher with 12 years' teaching experience, reflected on the conflicts and uncertainty 
of problem-solving-based learning. Specifically, Yi believed that "students do not engage in thinking and deep learning while listening to lectures." He thought that science learning should focus on the application of concepts to solving problems and so tended to agree with the pedagogical approaches promoted by the PISA test (which assesses students' science competencies, including their problem-solving ability). Nonetheless, Yi asserted that "[g]rowing up in a traditional lecture learning environment did not really inhibit [my] own critical-thinking ability." Consequently, Yi resorted to "a more traditional approach because it is more efficient in preparing students for good academic performance, which would lead them to a promising future."

On the other hand, Xiao and Ren, who have been teaching for 17 and 24 years, respectively, demonstrated a greater openness to reform-based curriculum and pedagogical practice and a more consistent view in terms of adopting learner-centered pedagogy and inquiry-based instructional approaches. After their exposure to active learning approaches, both teachers came to believe that "teachers should not suppress students' curiosity by asking them to behave and sit quietly in class." For example, Xiao shared that as a beginning teacher, he "used to believe that memorizing could lead to greater academic success." However, influenced by new trends in science learning that he discovered through professional colleagues and the media, he came to realize that memorizing factual knowledge did not stimulate students' thinking and curiosity. Thus, Xiao decided to explore different ways of encouraging his students to discover their own interests in science. He found that the philosophy of inquiry-based learning was indeed similar to the Confucian principle of ying cai shi jiao-to teach in accordance with the individual's ability. Xiao believed that "a good teacher should be able to meet the learning needs of his or her students." As he wrote in his reflective journal:

The Confucian teaching principle has continued to inspire my science instructional practice. I believe that teachers should be aware of the importance of knowing students' individual needs so that they could guide them in accordance with their interests and strengths.

Xiao and Ren explained that in their actual teaching practice, they had been trying to create a learning environment where students could engage in group activities and design their own learning tasks. However, they had to straddle between the two pedagogical paradigms due to the conflict between their teaching beliefs and the demands placed on them by the traditional national examination system. They further stated that they have been attempting to create a middle ground where they could pursue their inquiry-based pedagogical goals and find ways to address issues concerning the examinations. For example, Xiao has been trying out a combination of traditional and inquiry-based strategies to address his students' and parents' demands. He designed an online test to provide further training to his students for the standardized exams and also required them to practice the test questions at home. In his class, however, he has trying to engage the students in group activities and science experiments. Xiao noted, "Even though I still focus on preparing students for the exam, I have been trying to transform my teaching practice from an examoriented approach to one that increases students' interest in learning."

\section{Commitment to reform-based practice}

While the majority of the teachers in this study talked about various obstacles to activelearning approaches, Chang, a biology teacher and a teacher leader in professional development programs, seemed to be deeply committed to inquiry-based learning. Chang 
had a clear understanding of the reform policy goals and explained that his teaching objective focused on increasing students' interest in science, improving their scientific literacy and developing their inquiry skills to enable them to design scientific investigations. Chang shared that in order to achieve these objectives, he engages his students in problem-solving tasks where they could learn scientific knowledge through experiential learning. It is worth noting that Chang shared a similar perspective on Confucian epistemology with Xiao and Ren. Chang also believed in the Confucian tenet of yin cai shi jiao. However, Chang seemed to have a clear idea about the positive and negative aspects of Confucian heritage culture. He suggested that Confucianism has been used to control citizens' thinking. As Chang explained, 'Confucianism means teaching people about moral values and developing a sense of discipline in them... but the government has used these cultural traditions to discipline the citizens." He believed that an overemphasis on "social discipline and conformity" inhibits teachers' creativity and innovative thinking. In Chang's view, the need to prepare students for the national exams is the result of traditional Confucian values. He also contented that Confucian learning traditions could be found in the classroom practices of most Taiwanese teachers. According to him,

The Chinese government has linked Confucian traditions and virtues to national exam systems by rewarding the citizens who have followed the political role models promoted by the government. In an educational setting, Confucian values have been used to control teachers' and students' autonomy in Chinese history. Moreover, these values and cultural traditions have been used to treat knowledge like a commercial product... by linking education to career achievements.... When moral ethics, social disciplines and conformity are overemphasized by the government and educational system, teachers become less willing to embrace innovative ways of teaching.

Chang is committed to reform-based teaching in science. He shared that his teaching used to be based on traditional methods, but he has been making efforts to transform his instruction by using learner-centered strategies. As a facilitator for professional development programs that promote active learning approaches, Chang believed that assessments should be interwoven with classroom activities. For example, in his own science class, he has been assessing student engagement and participation in group activities. Based on his experience of using constructivist approaches in his teaching, Chang believed that learnercentered teaching strategies enabled him to understand and teach according to his students' diverse needs. When students are given autonomy and opportunities to demonstrate their diverse talents and creative ideas, they are "more engaged in classroom activities." The following table illustrates teachers' understanding of educational policy, their stance on inquiry-based teaching and the pedagogical strategies that they use while teaching (Table 2). In Table 3, we present excerpts from the teachers' interviews and reflective journals that illuminate how teachers' epistemological beliefs about Confucianism interact with their perspectives on learner-centered and inquiry-oriented learning approaches.

\section{Discussion: Teachers negotiating professional identity during Taiwan's educational change}

This study examined the ways in which science education reform has been unfolding in Confucian heritage culture. Although most teacher participants stated that they did not have any knowledge of the mandated changes in science education pedagogy, we found 
Table 2 Teacher's understanding of reform policy and their pedagogical commitment

\begin{tabular}{|c|c|c|c|}
\hline Teacher & $\begin{array}{l}\text { Understanding of science } \\
\text { education policy }\end{array}$ & Pedagogical practice & $\begin{array}{l}\text { Stance on traditional and } \\
\text { inquiry-based approaches }\end{array}$ \\
\hline
\end{tabular}

Committed to traditional practice

Jing Science education policy promotes student-centered teaching

Ting Science education policy means preparing students for the PISA exam

Yi Science education policy means preparing students for the PISA exam
Traditional lecture-based methods, memorization Focus on preparing for exams Ensure classroom discipline

Respect for teachers as experts and role models

Traditional lecture-based methods, memorization

Focus on preparing for exams

Ensure classroom discipline

Respect for teachers as experts and role models

Traditional lecture-based methods Focus on preparing for exams

Teachers provide knowledge, students have to think and apply that knowledge

Straddling between traditional and student-centered teaching approaches

$\mathrm{Hei}^{\mathrm{a}}$

Bao

Science education policy focuses on improving students' hands-on skills

Xiao Science education policy promotes inquiry-based teaching

Ren Science education policy promotes studentscentered teaching and inquiry-based learning
Traditional lecture-based methods

Focus on preparing for exam

Teachers provide knowledge, students have to think and apply that knowledge

Class discussions; students answer teachers' questions

Traditional lecture-based methods

Teachers provide knowledge, students have to think and apply that knowledge

Focus on improving students' hands-on skills

Teachers demonstrate experiments and provide opportunities for students to do experiments on their own

Traditional lecture-based methods Focus on preparing for exam

Teachers provide knowledge, students have to think and apply that knowledge

Group work and team activities

Meeting students' learning needs

Traditional lecture-based methods Focus on preparing for exam Group work and team activities Meeting students' learning needs Students lead their own learning, teachers facilitate
Traditional teaching is efficient and effective

Traditional teaching is efficient and effective

Traditional teaching is efficient, but may not be effective in meaningful learning

Traditional teaching is efficient, but may not be effective in meaningful learning

Traditional teaching is efficient, but may not be effective in meaningful learning

Use traditional methods, but willing to try inquirybased pedagogy with parents' support

Use traditional methods, but willing to try inquirybased pedagogy with parents' support 
Table 2 continued

\begin{tabular}{lllc}
\hline Teacher & $\begin{array}{l}\text { Understanding of science } \\
\text { education policy }\end{array}$ & Pedagogical practice & $\begin{array}{c}\text { Stance on traditional and } \\
\text { inquiry-based approaches }\end{array}$ \\
\hline Committed to reform-based practice & & \\
Chang & $\begin{array}{c}\text { Science education policy } \\
\text { aims to develop students }\end{array}$ & $\begin{array}{l}\text { Group work and team activities } \\
\text { Meeting students' learning needs } \\
\text { scientific literacy }\end{array}$ & $\begin{array}{c}\text { Implement inquiry-based } \\
\text { and student-centered } \\
\text { teachers facilitate } \\
\end{array}$ \\
& Constructivist approaches & \\
& &
\end{tabular}

${ }^{\text {a }}$ Hei did not share his understanding of the science education policy

that they had in fact been exposed to the discourse on interactive and learner-centered approaches in their professional communities. Most teachers shared that they had heard or learned about the concept of improving students' scientific inquiry skills by engaging in conversations with their colleagues and friends or by participating in the events initiated by the teachers in their local communities. Their knowledge, therefore, came from collective social expectations and dialogue around science education reforms in Taiwan and other parts of the world. These discourses may have imperceptibly influenced the teachers' beliefs about teaching and learning and inspired some shifts in their professional practice (Gee 2013). Thus, regardless of their understanding of the Taiwanese reform policy, the participants' ideas have been influenced by a peripheral knowledge of the current developments in science teaching and learning.

The findings of this study also illuminate the various ways in which science teachers in Taiwan continue to navigate through traditional and contemporary practices in science education. Although the reform in science education was meant to bring about a fundamental shift toward constructivist pedagogy in Taiwanese classrooms (Huang 2014), many teachers in this study still believed that direct teaching would best prepare students for success in Taiwan's examination-driven learning culture. Transforming educational practice is not easy in a learning culture where respect for tradition is highly valued; it requires a significant shift in teachers' epistemological beliefs about teaching and learning. For instance, in a Confucian cultural context, reform involves challenging teachers' beliefs about their role and relationship with students. In a similar study, Manhong Lai and Leslie Lo (2007) examined teachers' attitudes toward education reform in Hong Kong and Shanghai. They found that learner-centered approaches significantly affected teacherstudent relationships in these traditional learning cultures. Many teachers in Lai and Lo's study reported that they experienced a loss of control over students, which caused feelings of frustration and anxiety. Other studies have suggested that teachers' experience of feeling incompetent and frustrated might lead them to resist educational reform. When teachers are expected to adopt new practices, they often struggle with their own memories and experiences of learning, or they feel that they lack the skills to teach in new ways, especially if they have been teaching in traditional settings (Bradley and Lang 1994). In our study, Taiwanese teachers shared similar concerns regarding the challenge of using learnercentered approaches in their teaching. Importantly, the lack of professional support to help them address these challenges has led to significant dilemmas regarding their practice.

While the reform policy leaders promoted active and inquiry-based science teaching, the majority of the participants said that they have been struggling with the conflicts between the traditional and constructivist learning approaches. This conflict may have challenged teachers' cultural and professional identities. Marcia's (2002) theory on identity 
Table 3 Excerpts illustrating teachers' Confucian epistemologies and pedagogical practices

\begin{tabular}{lll}
\hline Confucian learning culture & $\begin{array}{l}\text { Teaching philosophy/ } \\
\text { pedagogical practice }\end{array}$ & Actual practice \\
\hline
\end{tabular}

Zhong Everyone in society should learn and live by the moral values of Confucianism, especially behaving in a disciplined manner and studying hard. This way, they can achieve their life goals

Ting Confucianism emphasized that learning with constant perseverance... everyone's on their best behavior to come for an education

Jing Confucianism is a heritage culture that should be preserved. It teaches students to be humble, have perseverance, be disciplined and learn with others

Hei The idea of you jiao wu leithere should be no class distinction with respect to teaching - in Confucianism should be cherished. This is what we strive for, where our students do not feel isolated, particularly those with disabilities and also those who are from lower-income families

Yi Confucianism indicates that we should teach all who want to learn. Because people have different competency levels, one should teach according to the student's competency

Bao Confucian values provide systematic guidance to inspire and motivate students to learn
As a teacher, my priority is to ensure students' discipline in class.... In order to maintain students' discipline in class, teachers and students cannot be friends.... Becoming too close to students could give them the misconception that they do not have to respect teachers

Learning as a cultural heritage to pass on Confucian traditions to the next generations for the sake of maintaining social harmony

I teach my students by using the way I used to learn as a student. I don't give my students autonomy in terms of curriculum design. My role as a teacher is to lead [my students'] learning process

As a teacher, my focus should be on what kind of environment we give to the student to inspire their curiosity about the world, to give them the opportunity to discover. Natural talents will allow them to develop the ability to explore [the world]

Teachers should care about and focus on the specific needs of all students

I believe that hands-on approaches can help result in better understanding and retention of knowledge
Lecturing is the most effective and efficient way of [teaching and] learning.... Most of the time, I prefer to give my students answers directly

I teach by writing on the blackboard while students quietly sit in the classroom and listen to the lecture

Students listen to my lectures and note down what I wrote on the blackboard to show that they are concentrating in class

Students' qualities are too different so I can only teach something very basic. Instead of teaching them how to think, I can only follow the instruction from textbooks

[I design my class to allow] my students to assess reading materials easily during the class. I also allow my students to ask as many questions as they can

My teaching goal is to help students remember the facts I taught 
Table 3 continued

\begin{tabular}{|c|c|c|c|}
\hline & Confucian learning culture & $\begin{array}{l}\text { Teaching philosophy/ } \\
\text { pedagogical practice }\end{array}$ & Actual practice \\
\hline Xiao & $\begin{array}{l}\text { Confucius promotes the idea of } \\
\text { ying cai shi jiao-teachers } \\
\text { should teach in line with the } \\
\text { student's ability.... [It } \\
\text { clearly explains] the } \\
\text { characteristic of a good } \\
\text { teacher is to focus on } \\
\text { meeting their needs rather } \\
\text { than judging and punishing } \\
\text { students by their behavior for } \\
\text { breaking the rules in class }\end{array}$ & $\begin{array}{l}\text { Testing how much detail } \\
\text { students can memorize } \\
\text { doesn't really lead to greater } \\
\text { success.... [Therefore], I } \\
\text { would like to transform my } \\
\text { teaching from an exam- } \\
\text { oriented approach to one that } \\
\text { increases students' interest in } \\
\text { learning }\end{array}$ & $\begin{array}{l}\text { I designed a classroom } \\
\text { learning environment by } \\
\text { using Confucian pedagogy, } \\
\text { which is to teach in line with } \\
\text { the student's ability }\end{array}$ \\
\hline Ren & $\begin{array}{l}\text { Confucian philosophy } \\
\text { promotes you jiao wu le- } \\
\text { every student has the same } \\
\text { right to education-so } \\
\text { teachers should not treat } \\
\text { their students differently } \\
\text { based on their } \\
\text { socioeconomic status and } \\
\text { performance }\end{array}$ & $\begin{array}{l}\text { Teachers should not suppress } \\
\text { students' curiosity and } \\
\text { inquiries by asking them to } \\
\text { behave and sit quietly in } \\
\text { class.... Teachers should } \\
\text { become learning partners to } \\
\text { their students, rather than } \\
\text { knowledge providers }\end{array}$ & $\begin{array}{l}\text { Teachers are influenced by } \\
\text { parents and by social } \\
\text { demands to keep on teaching } \\
\text { and reviewing until students } \\
\text { are extremely familiar with } \\
\text { the subject.... [so] I still have } \\
\text { to ask my students to } \\
\text { practice writing exams again } \\
\text { and again }\end{array}$ \\
\hline Chang & $\begin{array}{l}\text { Confucius encouraged teachers } \\
\text { to develop their students' } \\
\text { aptitudes }\end{array}$ & $\begin{array}{l}\text { I hope to be a catalyst for those } \\
\text { who may pursue science at } \\
\text { the professional level; I hope } \\
\text { to prompt greater interest in } \\
\text { these individuals so that they } \\
\text { can continue on their path } \\
\text { with science }\end{array}$ & $\begin{array}{l}\text { I have created a problem- } \\
\text { solving-based classroom, } \\
\text { where my students can } \\
\text { acquire scientific knowledge } \\
\text { through experience and by } \\
\text { conducting science } \\
\text { experiments }\end{array}$ \\
\hline
\end{tabular}

crisis provided a useful tool to interpret how these teachers mediated their professional identities while dealing with these struggles. We recognize identity construction as a dynamic process that involves ongoing negotiations between individuals and their broader sociocultural surroundings. As such, an individual might wrestle with different personal and professional identities in the context of educational change. Our analysis suggests that a number of teachers were experiencing difficult challenges while straddling between competing cultural and reform-based approaches to teaching. For example, some teachers in this study demonstrated firmly entrenched beliefs about the effectiveness of traditional approaches in promoting student learning and academic success in exams. These convictions were grounded in their own traditional learning experiences, which seemed meaningful to them. Inspired by Confucian values, these teacher participants believed that it was their professional responsibility to pass on important cultural and moral values to their students, such as diligence, humility, discipline and respect for their teachers' knowledge. In addition, these teachers deeply believed that teachers play an important role in developing students' ability to improve themselves and develop self-discipline during the learning process. They also believed that teachers must have expertise in content knowledge and they should act as role models for their students. These beliefs thus lay at the core of their professional identities. Learner-centered approaches, which encourage student autonomy and independent thinking, were therefore regarded as a challenge to their cultural learning traditions. For example, some teachers believed that learner-centered approaches required to develop a friendly relationships with their students. Teachers also 
emphasized the importance of students' following the classroom rules respectfully. Therefore, they tended to feel less confident in using learner-centered pedagogies as they believed that an equal teacher-student relationship might lead their students to neglect the importance of respecting teachers and other elders. In light of Marcia's (2002) identity construction framework, we suggest that these teachers' commitment to traditional teaching approaches was intricately tied to their cultural values.

On the other contrary, several teachers demonstrated more complex perspectives regarding the traditional and constructivist learning approaches. When we examined their teaching philosophies, we did not notice any clear commitment to a particular approach. In fact, they seemed to be struggling with competing values that underpin traditional and inquiry-centered approaches in Taiwan. Additionally, the teachers had to cope with external pressures imposed by the traditional assessment system. We suggest that these multiple internal conflicts also led to a fractured sense of their professional identity. For instance, they grappled with difficult questions such as, "Do I teach according to parents' expectations?" or "Should I use the inquiry approach, which I am not familiar with?" These dilemmas forced them to return to traditional lectures in science education or find a middle ground by combining traditional and inquiry-centered strategies. We reiterate here that teachers need constant professional support during educational reforms to effectively deal with such challenges (Day, Kingston, Stobart and Sammons 2006).

Another important finding that emerged from this analysis was that teachers interpreted Confucian philosophy of education in different ways to resist or embrace the new teaching and learning approaches. While some thought that Confucian traditions inhibit independent thinking and creativity in both teachers and students, others felt that Confucian principles of equality and equity in education are compatible with contemporary educational approaches. For instance, Chang and other teachers understood learner-centered teaching approaches to resonate with Confucius' principle of yin cai shi jiao, which dictates that teachers teach in accordance with their students' abilities. Chang's example suggests that his understanding of Confucius' concept of a good teacher has helped him to embrace the reform-based pedagogy.

\section{Final thoughts}

This study has important implications for improving science teaching and learning not only in Taiwan, but also in other international contexts. In particular, it can inform future research and professional development initiatives in East Asian contexts. The findings suggest that looking at teachers' understanding of reform policies as well as their cultural values, epistemological beliefs and pedagogical commitments are critical to the success of change initiatives. A better understanding of teachers' commitments to their cultural values and traditions could also help policymakers and educational leaders design more appropriate programs for professional growth and development.

Furthermore, upon discovering that teachers find local professional communities to be particularly effective in encouraging and sustaining new approaches, we conclude that providing sustained professional support to local teacher communities in reform contexts is crucial to enhancing the quality of education. In particular, we highlight the value of supporting school-based teacher communities, as most of our participants felt comfortable helping their students with their colleagues' support. Moreover, the findings suggest that teachers felt caught between the reform-based pedagogy and the requirements of the 
national entrance examinations. Although the reform policies expect teachers to use studentcentered and inquiry-based pedagogies, the teachers still believe that the national examinations mainly focus on knowledge memorization. Consequently, they seem to find the new approaches insufficient in terms of helping them prepare their students for the national examinations. At the same time, while the government has been encouraging teachers to prepare their students for the PISA assessment, which mainly focuses on students' understanding of scientific literacy and inquiry, the national examination system does not yet reflect the objectives of the PISA test. Faced with the pressure to prepare students for the national examinations, most teachers found themselves in a conflict situation where the curriculum goals have not been fully consistent with the focus of the national examination system. Therefore, policymakers need to realize that curriculum reform must be intimately tied to transformations in the assessment system, because consistency in both areas would help teachers to achieve their curriculum goals more effectively.

In Taiwan, the implementation of education reform could be strengthened by presenting teachers, parents and the larger community with successful examples of reform-based curricula in similar cultures and contexts. This would help the stakeholders-who might tend to adhere strongly to their traditional values - understand and support contemporary developments in science teaching and learning.

Although we had intended to explore the perspectives of both female and male teachers in this study, only two female teachers volunteered to participate. We recognize, therefore, that this study mainly presents the perspectives of male Taiwanese science teachers. We are also aware that these findings may not represent the views of all science teachers in Taiwan and that the participants' perspectives might have been influenced by their particular school and community contexts. However, we believe that this in-depth exploration, nonetheless, offers meaningful insights into some teachers' cultural and professional perspectives on the reform. Future studies could be conducted with teachers who have taught in accordance with the reform-based pedagogies and those who have yet to adapt the new teaching approaches, in order to get a more comprehensive understanding of different aspects of aligning or resisting the reform policies.

Open Access This article is distributed under the terms of the Creative Commons Attribution 4.0 International License (http://creativecommons.org/licenses/by/4.0/), which permits unrestricted use, distribution, and reproduction in any medium, provided you give appropriate credit to the original author(s) and the source, provide a link to the Creative Commons license, and indicate if changes were made.

\section{References}

Aikenhead, G. S. (2006). Science education for everyday life: Evidence-based practice. New York: Teachers College Press.

Alsup, J. (2006). Teacher identity discourses: Negotiating personal and professional spaces. Mahwah, NJ: Erlbaum.

Anderson, R. D. (2002). Reforming science teaching: What research says about inquiry. Journal of Science Teacher Education, 13(1), 1-12. doi:10.1080/01619567409537973.

Baron, A., \& Chen, H. S. (2012). Looking in a science classroom: Exploring possibilities of creative cultural divergence in science teaching and learning. Cultural Studies of Science Education, 7, 93-101. doi:10. 1007/s11422-012-9402-6.

Beauchamp, C., \& Thomas, L. (2009). Understanding teacher identity: An overview of issues in the literature and implications for teacher education. Cambridge Journal of Education, 39(2), 175-189. doi:10.1080/03057640902902252.

Beijaard, D., Verloop, N., \& Vermunt, J. D. (2000). Teachers' perceptions of professional identity: An exploratory study from a personal knowledge perspective. Teaching and Teacher Education, 16, 749764. doi: $10.1016 / \mathrm{s} 0742-051 \times(00) 00023-8$. 
Biggs, J. (1998). Learning from the Confucian heritage: So size doesn't matter? International Journal of Educational Research, 29, 723-738. doi:10.1016/s0883-0355(98)00060-3.

Blanchard, M. R., Southerland, S. A., \& Granger, E. M. (2009). No silver bullet for inquiry: Making sense of teacher change following an inquiry-based research experience for teachers. Science Education, 93, 322-360. doi:10.1002/sce.20298.

Bradley, M. M., \& Lang, P. J. (1994). Measuring emotion: The self-assessment manikin and the semantic differential. Journal of Behavior Therapy and Experimental Psychiatry, 25(1), 49-59. doi:10.1016/ 0005-7916(94)90063-9.

Bybee, R. W. (2002). Learning science and the science of learning: Science educators' essay collection. Arlington, VA: NSTA Press.

Cartier, J., Smith, M. S., Stein, M. K., \& Ross, D. (2013). 5 practices for orchestrating task-based discussions in science. Arlington, VA: National Science Teachers Association Press. doi:10.5951/ mathteacmiddscho.20.2.0124.

Chiu, M.-S., \& Whitebread, D. (2011). Taiwanese teachers implementation of a new constructivist mathematics curriculum: How cognitive and affective issues are addressed. International Journal of Educational Development, 31(2), 196-206. doi:10.1016/j.ijedudev.2010.06.014.

Chou, Z., \& Ching, G. S. (2012). Taiwan education at the crossroad: When globalization meets localization. New York, NY: Palgrave Macmillan. doi:10.1080/0046760x.2014.913698.

Cohen, D. K., \& Hill, H. C. (2001). Learning policy: When state education reform works. New Haven, CT: Yale University Press.

Collay, M. (2006). Respecting teacher professional identity as a foundational reform strategy. New Horizons for Learning. Retrieved at http://www.newhorizons.org/trans/collay.htm.

Confucius. (1907). K'ung-fu-tsze. In O. J. Thatcher (Ed. \& Trans.), The library of original sources: The ancient world (Vol. 1, pp. 382-411). New York: University Research Extension.

Confucius. (1960). Confucius and his immediate disciples. In J. Legge (Ed. \& Trans)., The Chinese classics: Confucian analects, the great learning, and the doctrine of the mean (pp. 56-128). Hong Kong: Hong Kong University Press.

Creswell, J. W. (2007). Qualitative inquiry and research design: Choosing among five approaches. Thousand Oaks, CA: Sage.

Danielewicz, J. (2001). Teaching selves: Identity, pedagogy, and teacher education. New York, NY: State University of New York Press. doi:10.1177/1524839915580941.

Day, C., Kingston, A., Stobart, G., \& Sammons, P. (2006). The personal and professional selves of teachers: Stable and unstable identities. British Educational Research Journal, 32, 601-616. doi:10.1080/ 01411920600775316.

Denzin, N. K., \& Lincoln, Y. S. (2000). Handbook of qualitative research. Thousand Oaks, CA: Sage.

Elman, B. A. (2000). A cultural history of civil examinations in late imperial China. Berkeley: University of California Press.

Erikson, E. H. (1968). Identity: Youth and crisis. New York, NY: Norton.

Feng, Y. (1995). From the imperial examination to the national college entrance examination: The dynamics of political centralism in China's educational enterprise. The Journal of Contemporary China, 4(8), 2856. doi:10.1080/10670569508724213.

Fosnot, C. T. (1996). Constructivism: Theory, perspectives, and practice. New York, NY: Teachers College Press.

Francis, B., \& Archer, L. (2005). British-Chinese pupils' and parents' constructions of the value of education. British Educational Research Journal, 31(1), 89-108. doi:10.1080/0141192052000310047.

Gardner, H. (2007). Responsibility at work: How leading professionals act (or don't act) responsibly. San Francisco, CA: Jossey-Bass. doi:10.1080/03057241003755028.

Gee, J. P. (2013). An introduction to discourse analysis: Theory and method. Abingdon: Routledge.

Hakanen, J. J., Bakker, A. B., \& Schaufeli, W. B. (2006). Burnout and work engagement among teachers. Journal of School Psychology, 43, 495-513. doi:10.1016/j.jsp.2005.11.001.

Hardy, S. A., \& Kisling, J. W. (2006). Identity statuses and prosocial behaviors in young adulthood: A brief report. Identity, 6, 363-369. doi:10.1207/s1532706xid0604_4.

Ho, D. Y. F., Peng, S. Q., \& Chan, S. F. F. (2001). Authority and learning in Confucian-heriatge education: A relational methodological analysis. In C. Chiu, F. Salili, \& Y. Hong (Eds.), Multiple competencies and self-regulated learning: Implications for multicultural education (pp. 29-48). Greenwich, CT: Information Age.

Holliday, A. (2002). Doing and writing qualitative research. Thousand Oaks, CA: Sage.

Huang, Y.-S. (2014). Science education reform in Confucian learning cultures: Policymakers' and science teachers' perspectives on policy and practice in Taiwan (Unpublished master's thesis). McGill University, Montreal, Canada. 
Jarvis-Selinger, S., Pratt, D. D., \& Regehr, G. (2012). Competency is not enough: Integrating identity formation into the medical education discourse. Academic Medicine, 87, 1185-1190. doi:10.1097/acm. 0b013e3182604968.

Kennedy, P. (2002). Learning cultures and learning styles: Myth-understandings about adult (Hong Kong) Chinese learners. International Journal of Lifelong Education, 21, 430-445. doi:10.1080/ 02601370210156745.

Kim, H. S. (2002). We talk, therefore we think? A cultural analysis of the effect of talking on thinking. Journal of Personality and Social Psychology, 83, 828-842. doi:10.1037/0022-3514.83.4.828.

Kirpal, S. (2004). Work identities of nurses: Between caring and efficiency demands. Career Development International, 9, 274-304. doi:10.1108/13620430410535850.

Kroger, J., Martinussen, M., \& Marcia, J. E. (2010). Identity status change during adolescence and young adulthood: A meta-analysis. Journal of Adolescence, 33, 683-698. doi:10.1016/j.adolescence.2009.11. 002.

Kyriacou, C., \& Chien, P. Y. (2004). Teacher stress in Taiwanese primary schools. Journal of Educational Enquiry, 5(2), 86-104.

Lai, K. (2008). An introduction to Chinese philosophy. Cambridge: Cambridge University Press.

Lai, M., \& Lo, L. N. (2007). Teacher professionalism in educational reform: The experiences of Hong Kong and Shanghai. Compare: A Journal of Comparative and International Education, 37, 53-68. doi:10. 1080/03057920601061786.

LeDoux, J. (1998). The emotional brain: The mysterious underpinnings of emotional life. New York, NY: Simon \& Schuster.

Li, J. (2001). Expectations of Chinese immigrant parents for their children's education: The interplay of Chinese tradition and the Canadian context. Canadian Journal of Education/Revue canadienne de l'éducation, 26(4), 477-494. doi:10.2307/1602178.

Li, J. (2003). The core of Confucian learning. The American Psychologist, 58(2), 146-147. doi:10.1037/ 0003-066x.58.2.146.

Lin, C.-J. (1983). The Republic of China (Taiwan). In R. M. Thomas \& T. N. Postlethwaite (Eds.), Schooling in East Asia: Forces of change-formal and nonformal education in Japan, the Republic of China, the People's Republic of China, South Korea, North Korea, Hong Kong, and Macau (pp. 104135). Oxford: Pergamon Press.

Lincoln, Y. S., \& Guba, E. G. (2013). The constructivist credo. Walnut Creek, CA: Left Coast Press.

Lu, T., Cowie, B., \& Jones, A. (2010). Senior high school student biology learning in interactive teaching. Research in Science Education, 40, 267-289. doi:10.1007/s11165-008-9107-8.

Luehmann, A. L. (2007). Identity development as a lens to science teacher preparation. Science Education, 91, 822-839. doi:10.1002/sce.20209.

Marcia, J. E. (1966). Development and validation of ego-identity status. Journal of Personality and Social Psychology, 3, 551-558. doi:10.1037/h0023281.

Marcia, J. E. (2002). Identity and psychosocial development in adulthood. Identity: An International Journal of Theory and Research, 2, 7-28. doi:10.1207/s1532706xid0201_02.

Maxwell, J. A. (1996). Qualitative research design: An interactive approach. Thousand Oaks, CA: Sage.

Ministry of Education, Republic of China (Taiwan). (2003). Ministry of Education white paper for science education. Retrieved from https:/www.most.gov.tw/most/attachments/7a2c05b5-a3d7-48c3-b4b0$50 f 404 \mathrm{~b} 585 \mathrm{ab}$.

Ministry of Education, Republic of China (Taiwan). (2012). Ministry of Education white paper on education. Retrieved from http://english.moe.gov.tw/public/Attachment/212241653371.pdf.

Ministry of Education. (2013, December 11). Educational fundamental act. Retrieved from http://edu. law.moe.gov.tw/EngLawContent.aspx?Type=E\&id=166.

Miyazaki, I. (1976). China's examination hell: The civil service examinations of Imperial China. New York: Weatherhill.

Mohan, B. A., \& Lo, W. A.-Y. (1985). Academic writing and Chinese students: Transfer and developmental factors. TESOL Quarterly, 19(3), 515-534. doi:10.2307/3586276.

Nguyen, P. M., Terlouw, C., \& Pilot, A. (2006). Culturally appropriate pedagogy: The case of group learning in a Confucian heritage culture context. Intercultural Education, 17, 1-19. doi:10.1080/ 14675980500502172.

Nivison, D. S., \& Van, N. B. W. (1996). The ways of Confucianism: Investigations in Chinese philosophy. Chicago, IL: Open Court.

Olsen, B. (2008). Introducing teacher identity and this volume. Teacher Education Quarterly, 35(3), 3-6.

Osborne, J., \& Dillon, J. (2008). Science education in Europe: Critical reflections-a report to the Nuffield Foundation. London: Nuffield Foundation. 
Pratt, M. G., Rockmann, K. W., \& Kaufmann, J. B. (2006). Constructing professional identity: The role of work and identity learning cycles in the customization of identity among medical residents. Academy of Management Journal, 49, 235-262. doi:10.5465/amj.2006.20786060.

Rao, N., \& Chan, C. K. K. (2009). Moving beyond paradoxes: Understanding Chinese learners and their teachers. In N. Rao \& C. K. K. Chan (Eds.), Revisiting the Chinese learner: Changing contexts, changing education (pp. 3-32). Hong Kong: Comparative Education Research Centre.

Reicher, S. (2004). The context of social identity: Domination, resistance, and change. Political Psychology, 25, 921-945. doi:10.1111/j.1467-9221.2004.00403.x.

Smith, L. K., \& Southerland, S. A. (2007). Reforming practice or modifying reforms? Elementary teachers' response to the tools of reform. Journal of Research in Science Teaching, 44, 396-423. doi:10.1002/tea. 20165.

Spillane, J. P., \& Thompson, C. L. (1997). Reconstructing conceptions of local capacity: The local education agency's capacity for ambitious instructional reform. Educational Evaluation and Policy Analysis, 19, 185-203. doi:10.2307/1164209.

Stephen, J., Fraser, E., \& Marcia, J. E. (1992). Moratorium-achievement (MAMA) cycles in lifespan identity development: Value orientations and reasoning system correlates. Journal of Adolescence, 15, 283300. doi:10.1016/0140-1971(92)90031-y.

Stevenson, H. W., \& Stigler, J. W. (1992). The learning gap: Why our schools are failing and what we can learn from Japanese and Chinese education. New York: Simon \& Schuster.

Stigler, J. W., \& Hiebert, J. (1998). Teaching is a cultural activity. American Educator, 22(4), 4-11.

Tao, Y., Oliver, M., \& Venville, G. (2013). A comparison of approaches to the teaching and learning of science in Chinese and Australian elementary classrooms: Cultural and socioeconomic complexities. Journal of Research in Science Teaching, 50, 33-61. doi:10.1002/tea.21064.

Tsai, C.-C., \& Kuo, P.-C. (2008). Cram school students' conceptions of learning and learning science in Taiwan. International Journal of Science Education, 30(3), 351-373. doi:10.1080/ 09500690701191425.

Tschannen-Moran, M., \& Hoy, W. K. (2000). A multidisciplinary analysis of the nature, meaning, and measurement of trust. Review of Educational Research, 70, 547-593.

Tu, C. S. (2007). Taiwan's educational reform and the future of Taiwan. Invited speech at the London School of Economics and Political Science, 10 Jan. http://www.lse.ac.uk/asiaResearchCentre/countries/ taiwan/TaiwanProgramme/Events/PublicLectures/TaiwanEducationalReform_English.pdf. Accessed 26 July 2015.

Tweed, R. G., \& Lehman, D. R. (2003). Confucian and Socratic learning. American Psychologist, 58, 148149. doi:10.3102/00346543070004547.

Van Veen, K., \& Sleegers, P. (2006). How does it feel? Teachers' emotions in a context of change. Journal of Curriculum Studies, 38, 85-111. doi:10.1080/00220270500109304.

Wang, J. (2013). Confucian Heritage Cultural Background (CHCB) as a descriptor for Chinese learners: The legitimacy. Asian Social Science. doi:10.5539/ass.v9n10p105.

Watkins, D., \& Biggs, J. B. (1996). The Chinese learner: Cultural, psychological, and contextual influences. Hong Kong: Comparative Education Research Centre.

Weimer, M. (2002). Learner-centered teaching: Five key changes to practice. San Francisco, CA: JosseyBass.

Yang, J. H., Huang, I. T. C., \& Aldridge, J. M. (2002). Investigating factors that prevent science teachers from creating positive learning environments in Taiwan. In S. W. Goh \& M. Khine (Eds.), Studies in educational learning environments: An international perspective (pp. 217-224). River Edge, NJ: World Scientific International Publishers. doi:10.1142/97898127771330010.

Yao, X. (1999). Confucianism and its modern values: Confucian moral, educational and spiritual heritages revisited. Journal of Beliefs and Values, 20, 30-40. doi:10.1080/1361767990200103.

Ying-Syaun Huang is a full-time doctoral student in the Math and Science Education Concentration program at McGill University. She graduated from National Taiwan Normal University with a Bachelor of Engineering in Graphics Arts and Communications and earned her Master of Arts in Education and Society at McGill University.

Anila Asghar is an Associate Professor in the Department of Integrated Studies in Education at McGill University. Prior to joining McGill she was an Assistant Professor at the Johns Hopkins School of Education. She received her doctorate in Education from Harvard University and did postdoctoral research at the Evolution Education Research Center at McGill University. 